LBNL-51715

April 21, 2003

\title{
Volatile Organic Compounds in Indoor Air: A Review of Concentrations Measured in North America Since 1990
}

\author{
ALFRED T. HODGSON ${ }^{\mathrm{a}, 1}$ and HAL LEVIN ${ }^{\mathrm{a}, \mathrm{b}}$ \\ ${ }^{a}$ Indoor Environment Department, Environmental Energy Technologies Division, E.O. Lawrence \\ Berkeley National Laboratory, Berkeley, CA, USA \\ ${ }^{\mathrm{b}}$ Building Ecology Research Group, Santa Cruz, CA, USA
}

\begin{abstract}
Central tendency and upper limit concentrations of volatile organic compounds (VOCs) measured in indoor air are summarized and reviewed. Data were obtained from published crosssectional studies of residential and office buildings conducted in North America from 1990 through the present. VOC concentrations in existing residences reported in 12 studies comprise the majority of the data set. Central tendency and maximum concentrations are compared between new and existing residences and between existing residences and office buildings. Historical changes in indoor VOC concentrations since the Clean Air Act Amendments of 1990 are explored by comparing the current data set with two published reviews of previous data obtained primarily in the 1980s. These historical comparisons suggest average indoor concentrations of some toxic air contaminants, such as 1,1,1-trichloroethane have decreased.

${ }^{1}$ Corresponding author:

Address: Lawrence Berkeley National Laboratory, MS 70-108B, Berkeley, CA 94720, USA. Tel.: +1-510-486-5301. Fax: +1-510-486-7303. E-mail: ATHodgson@1bl.gov
\end{abstract}




\section{Introduction}

Consideration of indoor exposures to air pollutants is critical to accurate assessments of the health risks associated with these chemicals because people spend a large fraction of their time indoors where concentrations of many airborne pollutants often tend to exceed ambient levels.

A California statewide activity pattern survey conducted in 1987-88 showed that individuals spent, on average, $87 \%$ of their time indoors (Jenkins et al., 1992). This was broken down into $65 \%$ of the time spent in a residence and $21 \%$ of the time spent in other indoor locations. The National Human Activity Pattern Survey conducted in 1992-94 produced similar results (Klepeis et al., 2001). Again, the mean percentage of time spent indoors was $87 \%$. This was broken down into $69 \%$ of time spent in a residence and $18 \%$ of the time spent in other indoor locations.

It is widely recognized that airborne concentrations of many toxic volatile organic compounds (VOCs) in residences, office buildings and some other indoor environments are higher than concentrations in outdoor air (e.g., Pellizzari et al., 1986; Wallace, 1987; Daisey et al., 1994). This occurs in part because there are numerous indoor sources of VOCs and because the relatively low rates of outdoor air ventilation typically used in residences and offices prevent the rapid dispersal of airborne contaminants. The many consumer products that are used in residences and offices contain and emit numerous VOCs. Such products include cleaners, air fresheners, and insect repellents. Combustion processes, in particular smoking, are indoor sources of complex mixtures of VOCs. Attached garages are a potential source of gasoline vapors due to evaporative and exhaust emissions. Materials and products used in new construction, remodeling, and redecorating are other major contributors to indoor VOC concentrations in residences and offices.

In the U.S. and elsewhere, the decade since 1990 has witnessed increased concern about the environmental consequences and adverse health effects of air pollution. Most significantly, the U.S. 1990 Clean Air Act (CAA) Amendments established Federal and State programs to regulate the emissions of a large number of air pollutants that can cause cancer, reproductive harm, other serious illnesses as well as environmental damage. These are classified as hazardous air 
pollutants (HAPs). A list of 189 HAPs was included in the 1990 CAA, and the U.S.

Environmental Protection Agency (EPA) was given authority to add new chemicals to the list or to remove chemicals (U.S. EPA, 1994). Source categories also were defined. Both large and small area sources are regulated and now must reduce their emissions of HAPs through curtailment and the use of control technologies. Cleaner fuels and engines have been mandated to reduce emissions of HAPs from mobile sources. In 1998, the EPA promulgated national VOC emissions standards for certain categories of consumer products as authorized under a section of the 1990 CAA. It is possible that concentrations of some HAPs to which people are exposed in buildings have been reduced due to reductions in outdoor air pollution and reformulation of materials and products.

Indoor VOC data from about 1978 through 1990 were summarized in several reviews. In the late 1980's, Shah and Singh (1988) updated and analyzed a VOC database for the U.S. Most of the available measurements of VOCs in ambient air and in residential and commercial buildings were gathered, with data accepted in all forms. The final database included 66 VOCs measured indoors. Average, median and upper and lower quartile concentrations were presented for 35 indoor VOCs. Brown et al. (1994) reviewed the literature and summarized the data on the concentrations of VOCs measured indoors in different categories of buildings (i.e., residences, offices, schools and hospitals). These included measurements reported in 50 studies, primarily in North America and northern Europe. Data were obtained for 90 VOCs occurring in residences. Considerably fewer data were available for the other building types. Holcomb and Seabrook (1995) compiled the data from 30 studies of houses and public places in North America and the United Kingdom, all conducted prior to 1990. Average concentrations were presented by environment for 18 of the 85 identified VOCs.

In this paper, we have compiled and summarized the data on the central tendency and upper limit indoor VOC concentrations measured from 1990 through the present. We have focused exclusively on measurements made in North America. Much of the available data are from studies of residences. Data from existing (i.e., not newly constructed) residences, new residences 
and primarily large office buildings are separately treated. VOC concentrations in other environments such as small offices, schools, retail stores and health care facilities generally have not been characterized and are not included. We also have not attempted to summarize indoor/outdoor concentration ratios. Our primary objective is to generate a database of typical and maximum VOC concentrations that can be used by others as a comparative basis for evaluating measured concentrations.

In a companion paper (Hodgson and Levin, In preparation), we assess the VOC concentrations in residences and office buildings summarized herein with respect to odor thresholds, derived sensory irritation levels for the general population and non-cancer chronic health risks. Our objective there is to identify VOCs that are most likely to result in comfort and/or health concerns and, therefore, that should be included in investigations of indoor air quality.

\section{Methods}

For this review, VOCs were broadly defined as chemical compounds based on carbon chains or rings with vapor pressures greater than $\sim 0.01$ millimeters of mercury at room temperature. Carbon monoxide, carbon dioxide, carbonic acid, metallic carbides, carbonate salts, and $\mathrm{C}_{1}-\mathrm{C}_{3}$ hydrocarbons were excluded.

Papers were gathered from the scientific journal literature with several exceptions. Papers were sought that reported measurements made in North American residences, both new and existing, and office buildings from 1990 through the present. Only cross-sectional studies that investigated five or more buildings were considered. Investigations of unusual environments or pollutant sources were excluded. One important probability-based study of residences was obtained as an agency report (Sheldon et al., 1991). A probability-based study of office buildings was obtained from the proceedings of an international conference (Girman et al., 1999). Finally, several very recent studies were obtained from the proceedings of Indoor Air

2002, the $9^{\text {th }}$ International Conference on Indoor Air Quality and Climate (Foster et al., 2002; 
Kurtz et al., 2002). In total, we identified 13 papers presenting the results of 12 studies of existing residences, two papers presenting results for new residences, and three papers presenting results for office buildings. Basic information regarding these studies (i.e., study type, location, collection dates, and number of building units) is summarized by building type in Tables 1-3.

For existing residences, there were five probability-based studies. One of these (Sheldon et al., 1992) provided complete population statistics including geometric means (GMs) and frequency distributions. More commonly, the existing residence studies presented central tendencies as median values or arithmetic averages. Upper concentration ranges were most frequently given as a maximum value and sometimes as $90^{\text {th }}$ and/or $95^{\text {th }}$ percentile values. For three existing residence studies (Heavner et al., 1995 and 1996; Mukerjee et al., 1997) in which the data were segmented (i.e., smoking and non-smoking residences or spring and summer seasons), GM concentrations weighted by the numbers of housing units in each segment were calculated for the entire study as described by Brown et al. (1994).

Only two studies of new residences encompassing 20 single-family houses were identified. The measurements were made within the first six months after the houses were completed. For one study (Hodgson et al., 2000), GM concentrations and ranges were presented for manufactured and site-built houses. GMs were summarized as weighted averages. For the other study (Lindstrom et al., 1995), all of the individual concentration measurements for pre- and post-occupancy phases were presented. These data were combined and summarized as GMs. The office building data were used as reported. For one study (Girman et al., 1999), the median and $95^{\text {th }}$ percentile values were extracted from a Log-scale plot.

Limited data editing was performed. Environmental tobacco smoke specific compounds (e.g., 3-ethenylpyridine and nicotine) reported by two studies (Heavner et al., 1995 and 1996) were excluded. Mukerjee et al. (1997) reported data for 70 volatile and very volatile, predominantly hydrocarbon compounds. Twenty-five of these were included; many very volatile compounds, compounds with low occurrence, and branched alkane hydrocarbon isomers generally were excluded. Van Winkle et al. (2001) reported data for 37 volatile and very volatile 
compounds. Only the 17 ubiquitous and often-found VOCs were included. Acrolein data reported by Lindstrom et al. (1995) were excluded as the method used likely underestimated the mass of this compound (Tejada, 1986).

All reported data were entered into a relational database (Microsoft Access). Concentrations given as mass per unit volume, i.e., $\mu \mathrm{g} \mathrm{m}^{-3}$ (the majority of studies) were converted to molar volume concentrations $(\mathrm{ppb})$ assuming a normal indoor temperature of $25^{\circ} \mathrm{C}\left(298^{\circ} \mathrm{K}\right)$ and one atmosphere pressure $(101 \mathrm{kPa})$. This conversion facilitates the inter-comparison of compounds with respect to health effects. Data summaries for individual studies were prepared as described above. In the tables, the compounds are grouped into 16 chemical classes and then, within each class, listed by decreasing volatility as indicated by boiling point.

\section{Results}

Table 4 lists the 106 VOCs for which concentration data were obtained along with their Chemical Abstract Service (CAS) numbers, chemical class, molecular weights, boiling points, $\mu \mathrm{g} / \mathrm{m} 3$ to ppb conversion factors, and toxic air pollutant list status. The EPA classifies 35 of these as HAPs. Five additional compounds are classified by the California EPA as Toxic Air Contaminants (CARB, 2003).

Central tendency data for existing residences were reported for 57 VOCs. These data are summarized in Table 5, which lists reported GM, median, and average concentrations. For compounds with data from two or more studies, a best estimate of central tendency is calculated as the unweighted GM of reported GM and median concentrations, with the GM selected to represent a study if both statistics were reported. All of the central tendency measures for 36 of the VOCs (63\%) were less than $1 \mathrm{ppb}$. These included the HAPs, n-hexane, 1,3-butadiene, styrene, isopropylbenzene (cumene), naphthalene, vinyl chloride, chloroform, carbon tetrachloride, trichloroethene, and 1,4-dioxane.

Upper concentration ranges for existing residences were reported for 48 VOCs. These data are summarized in Table 6 , which lists the reported $90^{\text {th }}$ and $95^{\text {th }}$ percentiles and maximum 
concentrations. For compounds with data from three or more studies, ranges are shown and maximum values are summarized as unweighted GMs. All of their upper concentration measures for seven of the VOCs including the HAPs, naphthalene, vinyl chloride, carbon tetrachloride, chlorobenzene, and bromomethane, were less than $1 \mathrm{ppb}$. VOCs with maximum concentrations of $50 \mathrm{ppb}$ or more included acetic acid, formaldehyde, toluene, $\mathrm{m} / \mathrm{p}$-xylene, 1,4-dichlorobenzene, dichloromethane, 1,1,1-trichloroethane, and 2-propanone.

Geometric mean and maximum concentration data from the two studies of new single-family houses are presented in Table 7. Data were reported for 69 VOCs. VOC concentrations reported by both studies are summarized as unweighted GMs. For 25 compounds (36\%), their GM concentrations were less than $1 \mathrm{ppb}$. These included all nine halogenated compounds. VOCs with maximum concentrations of $50 \mathrm{ppb}$ or more in the new houses included acetic acid, formaldehyde, acetaldehyde, hexanal, toluene, ethylene glycol, 1,2-propanediol, 2-propanone, and $\alpha$-pinene.

Central tendency (GMs or medians) and maximum concentration data from the three studies of office buildings are presented in Table 8. Data were reported for 67 VOCs. VOC concentrations reported by multiple studies were summarized as unweighted GMs. For 31 compounds (46\%), their central tendency values were less than $1 \mathrm{ppb}$. These included the HAPs, n-hexane, ethylbenzene, o-xylene, styrene, 1,4-dichlorobenzene, dichloromethane, and tetrachloroethene. For nine of the VOCs, including the HAPs, 1,2,4-trichlorobenzene, carbon tetrachloride, and chlorobenzene, the maximum concentrations also were less than $1 \mathrm{ppb}$. VOCs with maximum concentrations of $50 \mathrm{ppb}$ or more in the office buildings included ethanol, 2-propanol, n-octane, toluene, dichloromethane, 1,1,1-trichloroethane, and 2-propanone.

\section{Discussion}

\section{Data Limitations}

Published data are available for only a fraction of the VOCs that are known or suspected to occur in indoor air. The uncharacterized VOCs likely include a number of compounds important with 
respect to human health, sensory irritation and odor that have not been measured because they are inadequately collected or analyzed by conventional methods (Wolkoff et al., 1997; Wolkoff and Nielsen, 2001).

Several important indoor environments are inadequately represented. In particular, there were almost no published data available for small office buildings where the majority of office workers are located, schools, retail stores, other non-office commercial environments, and institutionalized housing.

The estimates of central tendency and upper limit concentrations may not be representative. Some of the studies were conducted in the early 1990's and may not represent current levels. Only a fraction of these studies were probability based. For some VOCs, only a small number of building units was represented. Most of the residential studies obtained only short-term samples and no study sampled a given environment more than a few times. Such strategies are dictated by practical considerations but may result in substantial misrepresentations of long-term indoor exposure concentrations and inadequate characterization of peak concentrations. In addition, personal breathing zone exposures which typically were not measured can be substantially higher than indoor area concentrations (Rhodes, 1990). The predominance of personal exposures was further demonstrated by the U.S. EPA TEAM studies (Wallace, 2001). Finally, very few studies measured building ventilation rates, which directly influence VOC concentrations and which may vary substantially with time within buildings.

\section{Comparisons Among Building Types}

Concentrations of VOCs emitted by interior building materials are expected to be higher initially in newly constructed buildings. Table 9 compares central tendency and maximum VOC concentrations for new residences with values for existing residences. Central tendency concentrations of several aldehydes (acetaldehyde, propionaldehyde, and benzaldehyde), normal alkane hydrocarbons and terpene hydrocarbons ( $\alpha$-pinene and d-limonene) were more three times (i.e., one-half order of magnitude) higher in the new houses than in the existing houses. 
Maximum concentrations of propionaldehyde, pentanal, acetic acid and 1,2-dichlorobenzene were more than three times higher in the new houses. Acetaldehyde, pentanal, and terpenes are emitted by composite wood products used for cabinetry and subfloors (Hodgson et al., 2002). Wood products probably also are a large source of acetic acid. Chloroform concentrations were lower in the new houses. This is expected, as these houses were unoccupied except for the final phase of one study (Lindstrom et al., 1995) with little domestic water use, a primary source of this compound. Some of the other lower values of chlorinated hydrocarbons in new houses also may be attributable to the difference in occupancy.

The sources of some VOCs may differ between residences and office buildings. Table 10 compares central tendency and maximum VOC concentrations for office buildings with values for existing residences. Central tendency concentrations of n-dodecane, 1,1,1-trichloroethane, trichloroethene and tetrachloroethene were more than three times higher in the office buildings. Dodecane is a component of an isoparaffinic solvent that was used in once prevalent wet-process photocopiers (Hodgson et al., 1991). The chlorinated solvents may be used in various office and janitorial products. The office buildings had lower central tendency concentrations of pentanal, $\alpha$-pinene, d-limonene, 1,4-dichlorobenzene, and dichloromethane. A lower prevalence of wood products in office buildings versus residences probably accounts for the lower pentanal and terpene concentrations. 1,4-Dichlorobenzene was once widely used in residences as a moth control agent. Maximum concentrations of the seven aromatic hydrocarbons were more than three times lower in office buildings.

\section{Historical Trends}

Changes in the production and use of environmentally harmful and toxic chemicals resulting from increased global awareness and the enactment in the U.S. of the 1990 CAA are expected to impact indoor concentrations and exposures to targeted HAPs in two ways. General reductions in the emissions, production, and use of HAPs should decrease the ambient concentrations of these compounds in ventilation and infiltration air entering buildings. Changes in industry 
processes to use less toxic compounds in consumer products and other materials used indoors should directly reduce indoor concentrations of the targeted HAPs. These latter changes, in particular, can result in substantial decreases in overall population exposures as shown by Lai et al. (2000). They developed the concept of inhalation transfer factors (ITFs) for outdoor and indoor pollutant emissions that accounts for dispersion in ambient air and ventilation dilution in well mixed buildings. Using ITFs, emissions of pollutants indoors were shown to result, on average, in three orders of magnitude higher exposures than equivalent emissions occurring outdoors in an urban air basin.

Potential historical changes in VOC concentrations were explored by comparing central tendency VOC concentrations from this review with results from the U.S. EPA TEAM studies. The TEAM studies measured concentrations of toxic VOCs in outdoor air, indoor air, personal exposure air and breath samples for communities in several states (i.e., NC, LA, TX, NJ and CA) from 1980 through 1984. Indoor samples were collected overnight at each residence and were analyzed for up to 30 VOCs. The indoor, residential median and maximum VOC concentrations were presented by Pellizzari et al. (1986). Because the measurements were probability based, limited to the U.S., and employed a consistent methodology, they provide a good benchmark for exploring potential historical changes in HAP concentrations. In Figure 1, the median and GM concentrations from the current review summarized as unweighted GMs are compared with the TEAM study's central tendency concentrations for 17 VOCs from nine studies also summarized as unweighted GMs. The 1,1,1-trichloroethane concentration in the current review is more than three times lower than the TEAM study value. Other compounds that are approximately onehalf order of magnitude lower in the current review are benzene, 1,2-dichloroethane and tetrachloroethene.

These changes likely are due to increased regulations. The 1990 London Amendment to the Montreal Protocol established timelines for global phase out of the production and consumption of CFCs, halons, 1,1,1-trichloroethane, and carbon tetrachloride. By 1995, the production and consumption of 1,1,1-trichloroethane in the U.S. were down by more than $80 \%$ relative to 1989 
with substantially larger decreases in subsequent years (Oberthur, 2001). The U.S. EPA estimated that nationwide tetrachloroethene emissions dropped 67\% from 1990 to 1996 (U.S. EPA, 2001). Measurements of benzene at urban monitoring sites throughout the U.S. showed an average 40\% reduction in benzene levels from 1994 to 1999 coincident with the phase-in of "tier 1" emissions standards for cars and increased regulation of oil refineries and chemical processes (ibid.). Other aromatic hydrocarbons associated with benzene may exhibit similar reductions.

\section{Conclusions}

There are few health-based guidelines for VOC concentrations in non-industrial indoor environments. Thus, summaries of indoor VOC concentrations typically measured in houses and offices provide one means for evaluating measured VOC concentrations. Although the available data were limited in a number of aspects, the summary of these data fills an important gap by covering the decade since the substantial 1990 revision of the Clean Air Act in the U.S. A comparison of the concentrations reviewed here with data from the previous decade suggests that average indoor concentrations of some toxic indoor air contaminants, such as benzene, 1,1,1-trichloroethane and tetrachloroethene, have decreased. Despite these trends, indoor exposures to most common VOCs undoubtedly still dominate human exposures to these compounds.

\section{Acknowledgements}

This work was supported by the Assistant Secretary for Energy Efficiency and Renewable Energy, Building Technologies Program of the U.S. Department of Energy under Contract No. DE-AC03-76SF00098. The authors thank Tosh Hotchi of LBNL for creating the Access database and assistance with data analysis. 


\section{References}

Adgate JL, Bollenbeck M, Eberly LE, Stroebel C, Pellizzari ED and Sexton K. 2002. Residential VOC concentrations in a probability-based sample of households with children. In Indoor Air 2002, Proc. $9^{\text {th }}$ Int. Conf. Indoor Air Quality and Climate, Vol. 1, pp. 203-208. H Levin (Ed.). Santa Cruz, CA: Indoor Air 2002.

Brown SK, Sim MR, Abramson MJ and Gray CN. 1994. Concentrations of volatile organic compounds in indoor air - a review. Indoor Air 4: 123-134.

CARB. 2003. Toxic air contaminant identification list. Air Quality Measures Branch, California Air Resources Board, Sacramento, CA. Web site http://www.arb.ca.gov./toxics/id.htm.

Clayton CA, Pellizzari ED, Whitmore RW, Perritt RL and Quackenboss JJ. 1999. National Human Exposure Assessment Survey (NHEXAS): distributions and associations of lead, arsenic and volatile organic compounds in EPA Region 5. J. Expos. Anal. Environ. Epidemiol. 9: 381-392.

Daisey, JM, Hodgson AT, Fisk WJ. Mendell MJ and Ten Brinke J. 1994. Volatile organic compounds in twelve California office buildings: classes, concentrations and sources. Atmos. Environ. 28: 3557-3562.

Foster SJ, Kurtz JP and Woodland AK. 2002. Background indoor air risks in selected residences in Denver Colorado. In Indoor Air 2002, Proc. $9^{\text {th }}$ Int. Conf. Indoor Air Quality and Climate, Vol. 1, pp. 932-937. H Levin (Ed.). Santa Cruz, CA: Indoor Air 2002.

Girman JR, Hadwen GE, Burton LE, Womble SE and JF McCarthy. 1999. Individual volatile organic compound prevalence and concentrations in 56 buildings of the Building Assessment Survey and Evaluation (BASE) study. In Indoor Air 99, Proc. $8^{\text {th }}$ Int. Conf. Indoor Air Quality and Climate, Vol. 2, pp. 460-465. G Raw, C Aizlewood, and P Warren (Eds.). London: Construction Research Communications Ltd.

Gordon SM, Callahan PJ, Nishioka MG, et al. 1999. Residential environmental measurements in the National Human Exposure Assessment Survey (NHEXAS) pilot study in Arizona: preliminary results for pesticides and VOCs. J. Expos. Anal. Environ. Epidemiol. 9: 456-470.

Heavner DL, Morgan WT and Ogden MW. 1995. Determination of volatile organic compounds and ETS apportionment in 49 homes. Environ. Int. 21: 3-21.

Heavner DL, Morgan WT and Ogden MW. 1996. Determination of volatile organic compounds and respirable suspended particulate matter in New Jersey and Pennsylvania homes and workplaces. Environ. Int. 22: 159-183.

Hodgson AT, Daisey JM and Grot RA. 1991. Sources and source strengths of volatile organic compounds in a new office building. J. Air Waste Manage. Assoc. 41: 1461-1468.

Hodgson AT, Rudd AF, Beal D and Chandra S. 2000. Volatile organic compound concentrations and emission rates in new manufactured and site-built houses. Indoor Air 10: 178-192.

Hodgson AT, Beal D and Mcllvaine JER. 2002. Sources of formaldehyde, other aldehydes and terpenes in a new manufactured house. Indoor Air 12: 1-8.

Hodgson AT and Levin H. In preparation. Volatile organic compounds in indoor air: concentrations of interest with respect to noncancer effects. 
Holcomb, LC and Seabrook BS. 1995. Indoor concentrations of volatile organic compounds: implications for comfort, health and regulation. Indoor Environment 4: 7-26.

Jenkins PL, Phillips TJ, Mulberg EJ and Hui SP. 1992. Activity patterns of Californians: use of and proximity to indoor pollutant sources. Atmos. Environ. 26A: 2141-2148.

Klepeis NE, Nelson WC, Ott WR, et al. 2001. The National Human Activity Pattern Survey (NHAPS): a resource for assessing exposure to environmental pollutants. J. Expos. Anal. Environ. Epidemiol. 11: 231-252.

Kurtz JP and Folkes DJ. 2002. Background concentrations of selected chlorinated hydrocarbons in residential indoor air. In Indoor Air 2002, Proc. $9^{\text {th }}$ Int. Conf. Indoor Air Quality and Climate, Vol. 1, pp. 920-925. H Levin (Ed.). Santa Cruz, CA: Indoor Air 2002.

Lai ACK, Thatcher TL and Nazaroff WW. 2000. Inhalation transfer factors for air pollution health-risk assessments. J. Air Waste Manage. Assoc. 50: 1688-1699.

Lindstrom AB, Proffitt D and Fortune CR. 1995. Effects of modified residential construction on indoor air quality. Indoor Air 5: 258-269.

Mukerjee S, Ellenson WD, Lewis RG, et al. 1997. An environmental scoping study in the lower Rio Grande Valley of Texas - III. Residential micoenvironmental monitoring for air, house dust, and soil. Environ. Int. 23: 657-673.

Oberthur, S. 2001. Production and consumption of ozone-depleting substances 1986-1999. Publication. Eschborn, Germany: GTZ/Proklima.

Otson R, Fellin P and Tran Q. 1994. VOCs in representative Canadian residences. Atmos. Environ. 28: 3563-3569.

Pellizzari ED, Hartwell TD, Perritt RL, et al. 1986. Comparison of indoor and outdoor residential levels of volatile organic chemicals in five U.S. geographical areas. Environ. Int. 12: 619-623.

Rhodes CE, Kamens RM and Wiener RW. 1991. The significance and characteristics of the personal activity cloud on exposure assessment measurement for indoor contaminants. Indoor Air 1: 123-145.

Shah JJ and Singh HB. 1988. Distribution of volatile organic chemicals in outdoor and indoor air. Environ. Sci. Technol. 22: 1381-1388.

Shields HC, Fleischer DM and Weschler CJ. 1996. Comparisons among VOCs measured in three types of U.S. commercial buildings with different occupant densities. Indoor Air 6: 2-17.

Sheldon LS, Clayton A, Jones B, et al. 1991. Indoor Pollutant Concentrations and Exposures. Final report. Sacramento, CA: California Air Resources Board.

Tejada SB. 1986. Evaluation of silica gel cartridges coated in situ with acidified 2,4dinitrophenylhydrazine for sampling aldehydes and ketones in air. Int. J. Environ. Anal. Chem. 26: 167-185.

U.S. EPA. 1994. EPA health effects notebook for hazardous air pollutants-draft. Air Risk Information Support Center, Office of Air Quality Planning and Standards, U.S. Environmental Protection Agency, Washington, DC. EPA-452/D-95-00. U.S. EPA Air Toxics web site: http://www.epa.gov/ttn/atw/. 
U.S. EPA. 2001. Latest findings on National air quality: 2000 status and trends. Report EPA 454/K-01-002. Research Triangle Park, NC: U.S. Environmental Protection Agency.

Van Winkle MR and Scheff PA. 2001. Volatile organic compounds, polycyclic aromatic hydrocarbons and elements in the air of ten urban homes. Indoor Air 11: 49-64.

Wallace LA, Pellizzari ED, Hartwell TD, et al. 1986. Total Exposure Assessment Methodology (TEAM) study: personal exposures, indoor-outdoor relationships, and breath levels of volatile organic compounds in New Jersey. Environ. Int. 12: 369-387.

Wallace LA. 1987. The Total Exposure Assessment Methodology (TEAM) Study: Summary and Analysis: Volume I. EPA/600/6-87/002a. Washington, DC: Office of Research and Development, US EPA.

Wallace LA, Pellizzari ED, Hartwell TD, et al. 1988. The California TEAM study: breath concentrations and personal exposures to 26 volatile compounds in air and drinking water of 188 residents of Los Angeles, Antioch and Pittsburg, CA. Atmos. Environ. 22: 2141-2163.

Wallace LA. 2001. Assessing human exposure to volatile organic compounds. In Indoor Air Quality Handbook, pp. 33.1-33.35. JD Spengler, JM Samet, and JF McCarthy (Eds.). New York, NY: McGraw-Hill.

Wolkoff P, Clausen PA, Jensen B, Nielsen GD and Wilkins CK. 1997. Are we measuring the relevant indoor pollutants? Indoor Air 7: 92-106.

Wolkoff P and Nielsen GD. 2001. Organic compounds in indoor air - their relevance for perceived indoor air quality. Atmos. Environ. 35: 4407-4417.

Zhang J, He Q and Lioy PJ. 1994. Characteristics of aldehydes: concentrations, sources and exposures for indoor and outdoor residential microenvironments. Environ. Sci. Technol. 28: 146-152.

Zhang J, Wilson W and Lioy PJ. 1994. Sources of organic acids in indoor air: a field study. 1994. J. Expos. Anal. Environ. Epidemiol. 4: 25-47. 
Table 1. Residential studies included in review. Probability-based studies are listed first.

\begin{tabular}{|c|c|c|}
\hline Reference (ID) & Parameter & Data \\
\hline $\begin{array}{l}\text { Sheldon et al. (s) } \\
1992\end{array}$ & $\begin{array}{l}\text { Study type } \\
\text { Loc. \& Date } \\
\text { No. units } \\
\text { Data source }\end{array}$ & $\begin{array}{l}\text { Stratified probability sample } \\
\text { Woodland, CA; Jun } 1990 \\
\text { 128 Residences } \\
\text { Tbls. 9-13, 9-14, 9-18 }\end{array}$ \\
\hline $\begin{array}{l}\text { Otson et al. (o) } \\
1994\end{array}$ & $\begin{array}{l}\text { Study type } \\
\text { Loc. \& Date } \\
\text { No. units } \\
\text { Data source }\end{array}$ & $\begin{array}{l}\text { Probability sample } \\
\text { Canada; Date not specified } \\
757 \text { Housing units } \\
\text { Tbl. 1, p. } 3564\end{array}$ \\
\hline $\begin{array}{l}\text { Clayton et al. (c) } \\
1999\end{array}$ & $\begin{array}{l}\text { Study type } \\
\text { Loc. \& Date } \\
\text { No. units } \\
\text { Data source }\end{array}$ & $\begin{array}{l}\text { Stratified, 4-stage probability sample } \\
\text { IL, OH, MI, MN, WI; Jul } 1995 \text { - May } 1997 \\
\sim 170 \text { Housing units, sampled up to } 3 \text { times } \\
\text { Tbl. 7, p. } 387\end{array}$ \\
\hline $\begin{array}{l}\text { Gordon et al. (g) } \\
1999\end{array}$ & $\begin{array}{l}\text { Study type } \\
\text { Loc. \& Date } \\
\text { No. units } \\
\text { Data source }\end{array}$ & $\begin{array}{l}\text { Stratified, 3-stage probability sample } \\
\text { AZ; Date not specified } \\
\sim 190 \text { Housing units } \\
\text { Tbls. } 10 \& 11 \text {, pp. } 467-468\end{array}$ \\
\hline $\begin{array}{l}\text { Adgate et al. (a) } \\
2002\end{array}$ & $\begin{array}{l}\text { Study type } \\
\text { Loc. \& Date } \\
\text { No. units } \\
\text { Data source }\end{array}$ & $\begin{array}{l}\text { Stratified probability sample; units with children } \\
\text { MN; May - Aug } 1997 \\
\sim 290 \text { Housing units } \\
\text { Tbl. } 2 \text { \& Fig. 1, Vol. 1, pp. 205-206 }\end{array}$ \\
\hline $\begin{array}{l}\text { Zhang et al. }(\mathrm{za}, \mathrm{zb}) \\
\text { 1994a \& b }\end{array}$ & $\begin{array}{l}\text { Study type } \\
\text { Loc. \& Date } \\
\text { No. units } \\
\text { Data source }\end{array}$ & $\begin{array}{l}\text { Convenience sample } \\
\text { NJ; Jun - Aug, } 1992 \\
6 \\
\text { Tbl. 1, p. 148; Tbl. 2, p. } 32\end{array}$ \\
\hline $\begin{array}{l}\text { Heavner et al. (ha) } \\
1995\end{array}$ & $\begin{array}{l}\text { Study type } \\
\text { Loc. \& Date } \\
\text { No. units } \\
\text { Data source }\end{array}$ & $\begin{array}{l}\text { Convenience sample; units with married non-smoking } \\
\text { females } \\
\text { Columbus, OH; Feb } 1991 \\
24 \text { Non-smoking units, } 25 \text { smoking units } \\
\text { Tbl. 1, p. } 7\end{array}$ \\
\hline $\begin{array}{l}\text { Heavner } \text { et al. (hb) } \\
1996\end{array}$ & $\begin{array}{l}\text { Study type } \\
\text { Loc. \& Date } \\
\text { No. units } \\
\text { Data source }\end{array}$ & $\begin{array}{l}\text { Convenience sample; units with married non-smoking } \\
\text { females } \\
\text { Mt. Laurel, NJ; Nov } 1992 \\
61 \text { Non-smoking units, } 32 \text { smoking units } \\
\text { Tbl. 4, p. } 169\end{array}$ \\
\hline $\begin{array}{l}\text { Mukerjee et al. (m) } \\
1997\end{array}$ & $\begin{array}{l}\text { Study type } \\
\text { Loc. \& Date } \\
\text { No. units } \\
\text { Data source }\end{array}$ & $\begin{array}{l}\text { Convenience sample } \\
\text { Brownsville, TX; } 1993 \\
3 \text { City units, } 6 \text { rural agricultural units } \\
\text { Tbl. 8, pp. 668-669 }\end{array}$ \\
\hline
\end{tabular}


Table 1. Continued.

\begin{tabular}{lll}
\hline Reference (ID) & Parameter & Data \\
\hline Van Winkle et al. & Study type & Convenience sample of non-smoking units \\
(v) 2001 & Loc. \& Date & Chicago, IL; 1994 - 1995 \\
& No. units & 10 Units sampled monthly or quarterly \\
& Data source & Tbl. 1, pp. 52-53 \\
Kurtz \& Folkes (k) & Study type & Convenience sample \\
2002 & Loc. \& Date & Denver, CO; 1998 - 2001 \\
& No. units & 120 Single-family residences in Redfield Rifle Scope site \\
& Data source & Tbl. 1, Vol. 1, p. 923 \\
Foster et al. (f) & Study type & Convenience sample \\
2002 & Loc. \& Date & Denver, CO; 1996- 2001 \\
& No. units & 21 Single-family resid., 8 town house; 12 apart.bldg. \\
& Data source & Tbl. 2, Vol. 1, p. 935 \\
\hline
\end{tabular}


Table 2. Studies of new residences included in review.

\begin{tabular}{lll}
\hline Reference (ID) & Parameter & Data \\
\hline \multirow{2}{*}{ Lindstrom et al. (1) } & Study type & Convenience sample \\
& Loc. \& Date & Denver, CO; Dec 1992 - May 1993 \\
& No. units & 6 Experimental \& 3 conventional single-family houses \\
& Data source & Tbls. 6, 8, 9 \& 11, pp. 262, 265 \& 267 \\
Hodgson et al. (ho) & Study type & Convenience sample \\
& Loc. \& Date & FL \& east, southeast U.S.; 1997 - 1998 \\
& No. units & 4 Manufactured houses; 7 site-built single-family houses \\
& Data source & Tbls. 3 \& 4, pp. 668-669 \\
\hline
\end{tabular}

Table 3. Office building studies included in review.

\begin{tabular}{|c|c|c|}
\hline Reference (ID) & Parameter & Data \\
\hline $\begin{array}{l}\text { Daisey et al. (d) } \\
1994\end{array}$ & $\begin{array}{l}\text { Study type } \\
\text { Loc. \& Date } \\
\text { No. units } \\
\text { Data source }\end{array}$ & $\begin{array}{l}\text { Convenience } \\
\text { San Francisco Bay Area, CA; Jun - Sep } 1990 \\
12 \text { Public buildings ( } 3 \text { natural vent., } 3 \text { mech. vent., } 6 \\
\text { mech. vent. with AC) } \\
\text { Tbl. 2, p. } 3559\end{array}$ \\
\hline $\begin{array}{l}\text { Shields et al. (sh) } \\
1996\end{array}$ & $\begin{array}{l}\text { Study type } \\
\text { Loc. \& Date } \\
\text { No. units } \\
\text { Data source }\end{array}$ & $\begin{array}{l}\text { Convenience } \\
\text { U.S.; Mar - Apr } 1991 \\
11 \text { Telco administrative offices } \\
\text { Tbl. 3, p. } 8\end{array}$ \\
\hline $\begin{array}{l}\text { Girman et al. (gi) } \\
1999\end{array}$ & $\begin{array}{l}\text { Study type } \\
\text { Loc. \& Date } \\
\text { No. units } \\
\text { Data source }\end{array}$ & $\begin{array}{l}\text { Stratified probability sample } \\
\text { U.S., } 1995 \text { - } 1998 \\
\text { 56 Public \& private buildings } \\
\text { Tbl. } 1 \text { \& Fig. 1; Vol. 2, pp. } 462 \& 464\end{array}$ \\
\hline
\end{tabular}


Table 4. VOCs reported in existing and new residences and in office buildings ordered by chemical class and increasing boiling point within class. Factors for $\mu \mathrm{g} / \mathrm{m}^{3}$ to $\mathrm{ppb}$ concentration conversions are shown. Presence on U.S. EPA Hazardous Air Pollutant (H) and California EPA Toxic Air Contaminant (T) lists is indicated.

\begin{tabular}{|c|c|c|c|c|c|c|}
\hline Compound & $\begin{array}{l}\text { CAS } \\
\text { No. }\end{array}$ & $\begin{array}{l}\text { Chem. } \\
\text { Class }^{\mathrm{a}}\end{array}$ & $\begin{array}{l}\mathrm{BP} \\
\left({ }^{\circ} \mathrm{C}\right) \\
\end{array}$ & MW & $\begin{array}{l}\mu \mathrm{g} / \mathrm{m}^{3} \\
\text { to } \mathrm{ppb}\end{array}$ & $\begin{array}{c}\text { Toxic } \\
\text { Cat. }\end{array}$ \\
\hline Ethanol & $64-17-5$ & Alc & 78 & 46.1 & 0.530 & \\
\hline 2-Propanol & $67-63-0$ & Alc & 82 & 60.1 & 0.407 & \\
\hline 1-Butanol & $71-36-3$ & Alc & 118 & 74.1 & 0.330 & $\mathrm{~T}$ \\
\hline Phenol & $108-95-2$ & Alc & 182 & 94.1 & 0.260 & $\mathrm{H}, \mathrm{T}$ \\
\hline 2-Ethyl-1-hexanol & $104-76-7$ & Alc & 183 & 130.2 & 0.188 & \\
\hline 1-Octanol & $111-87-5$ & Alc & 195 & 130.2 & 0.188 & \\
\hline Butylated hydroxytoluene & $128-37-0$ & Alc & 265 & 220.4 & 0.111 & \\
\hline$t$-Butyl methyl ether & $1634-04-4$ & Ethr & 20 & 88.2 & 0.277 & $\mathrm{H}, \mathrm{T}$ \\
\hline 1,4-Dioxane & $123-91-1$ & Ethr & 101 & 88.1 & 0.278 & $\mathrm{H}, \mathrm{T}$ \\
\hline Ethylene glycol & $107-21-1$ & Gly & 19 & 62.1 & 0.394 & $\mathrm{H}, \mathrm{T}$ \\
\hline 2-Butoxyethanol & $111-76-2$ & Gly & 171 & 118.2 & 0.207 & $\mathrm{H}, \mathrm{T}$ \\
\hline 1,2-Propanediol & $57-55-6$ & Gly & 188 & 76.1 & 0.321 & \\
\hline 2-(2-Butoxyethoxy)ethanol & $112-34-5$ & Gly & 231 & 162.2 & 0.151 & $\mathrm{H}, \mathrm{T}$ \\
\hline 2-Propanone & $67-64-1$ & Ket & 56 & 58.1 & 0.421 & \\
\hline 2-Butanone & $78-93-3$ & Ket & 80 & 72.1 & 0.339 & $\mathrm{H}, \mathrm{T}$ \\
\hline 4-Methyl-2-pentanone & $108-10-1$ & Ket & 117 & 100.2 & 0.244 & $\mathrm{H}, \mathrm{T}$ \\
\hline Cyclohexanone & $108-94-1$ & Ket & 156 & 98.2 & 0.249 & \\
\hline 1-Phenylethanone & $98-86-2$ & Ket & 202 & 120.2 & 0.203 & $\mathrm{H}, \mathrm{T}$ \\
\hline Formaldehyde & $50-00-0$ & Ald & -19 & 30.0 & 0.815 & $\mathrm{H}, \mathrm{T}$ \\
\hline Acetaldehyde & $75-07-0$ & Ald & 20 & 44.1 & 0.554 & $\mathrm{H}, \mathrm{T}$ \\
\hline Propionaldehyde & $127-38-6$ & Ald & 48 & 58.1 & 0.421 & \\
\hline Acrolein & $107-02-8$ & Ald & 53 & 56.1 & 0.436 & $\mathrm{H}, \mathrm{T}$ \\
\hline Butanal & $123-72-8$ & Ald & 75 & 72.1 & 0.339 & \\
\hline 3-Methylbutanal & $590-86-3$ & Ald & 90 & 86.1 & 0.284 & \\
\hline Pentanal & $110-62-3$ & Ald & 103 & 86.1 & 0.284 & \\
\hline Hexanal & $66-25-1$ & Ald & 128 & 100.2 & 0.244 & \\
\hline Heptanal & $111-71-7$ & Ald & 153 & 114.2 & 0.214 & \\
\hline 2-Furaldehyde & $98-01-1$ & Ald & 162 & 96.1 & 0.254 & \\
\hline Octanal & $124-13-0$ & Ald & 174 & 128.2 & 0.191 & \\
\hline Benzaldehyde & $100-52-7$ & Ald & 179 & 106.1 & 0.230 & \\
\hline Nonanal & $124-19-6$ & Ald & 195 & 142.2 & 0.172 & \\
\hline Ethyl acetate & $141-78-6$ & Estr & 77 & 88.1 & 0.278 & \\
\hline Butyl acetate & $123-86-4$ & Estr & 126 & 116.2 & 0.210 & \\
\hline TMPD-MIB $^{\mathrm{b}}$ & $25265-77-4$ & Estr & 244 & 216.3 & 0.113 & \\
\hline TMPD-DIB $^{\mathrm{c}}$ & $6846-50-0$ & Estr & 280 & 286.4 & 0.085 & \\
\hline Diethyl phthalate & $84-66-2$ & Estr & 298 & 222.2 & 0.110 & \\
\hline
\end{tabular}


Table 4. Continued.

\begin{tabular}{|c|c|c|c|c|c|c|}
\hline Compound & $\begin{array}{l}\text { CAS } \\
\text { No. }\end{array}$ & $\begin{array}{l}\text { Chem. } \\
\text { Class }^{\text {a }}\end{array}$ & $\begin{array}{c}\text { BP } \\
\left({ }^{\circ} \mathrm{C}\right) \\
\end{array}$ & MW & $\begin{array}{l}\mu \mathrm{g} / \mathrm{m}^{3} \\
\text { to } \mathrm{ppb}\end{array}$ & $\begin{array}{l}\text { Toxic } \\
\text { Cat. }\end{array}$ \\
\hline Formic acid & $64-18-6$ & Acid & 100 & 46.0 & 0.532 & \\
\hline Acetic acid & $64-19-7$ & Acid & 118 & 60.0 & 0.408 & \\
\hline Hexanoic acid & $142-62-1$ & Acid & 206 & 166.2 & 0.147 & \\
\hline n-Pentane & $109-66-0$ & Alka & 36 & 72.2 & 0.339 & \\
\hline 2-Methylpentane & $107-83-5$ & Alka & 60 & 86.2 & 0.284 & \\
\hline 3-Methylpentane & $96-14-0$ & Alka & 64 & 86.2 & 0.284 & \\
\hline n-Hexane & $110-54-3$ & Alka & 69 & 86.2 & 0.284 & $\mathrm{H}, \mathrm{T}$ \\
\hline 3-Methylhexane & $589-34-4$ & Alka & 91 & 100.2 & 0.244 & \\
\hline n-Heptane & $142-82-5$ & Alka & 98 & 100.2 & 0.244 & \\
\hline 2,2,5-Trimethylhexane & $3522-94-9$ & Alka & 124 & 128.3 & 0.191 & \\
\hline n-Octane & $111-65-9$ & Alka & 126 & 114.2 & 0.214 & \\
\hline $\mathrm{n}$-Nonane & $111-84-2$ & Alka & 151 & 128.3 & 0.191 & \\
\hline n-Decane & $124-18-5$ & Alka & 174 & 142.3 & 0.172 & \\
\hline n-Undecane & $1120-21-4$ & Alka & 196 & 156.3 & 0.156 & \\
\hline n-Dodecane & $112-40-3$ & Alka & 216 & 170.3 & 0.144 & \\
\hline n-Tridecane & $629-50-5$ & Alka & 236 & 184.4 & 0.133 & \\
\hline $\mathrm{n}$-Tetradecane & $629-59-4$ & Alka & 252 & 198.4 & 0.123 & \\
\hline n-Pentadecane & $629-62-9$ & Alka & 270 & 212.4 & 0.115 & \\
\hline n-Hexadecane & $544-76-3$ & Alka & 287 & 226.4 & 0.108 & \\
\hline Methylcyclopentane & $96-37-7$ & Cycl & 72 & 84.2 & 0.290 & \\
\hline Cyclohexane & $110-82-7$ & Cycl & 81 & 84.2 & 0.290 & $\mathrm{~T}$ \\
\hline Methylcyclohexane & $108-87-2$ & Cycl & 100 & 98.2 & 0.249 & \\
\hline Propylcyclohexane & $1678-92-8$ & Cycl & 155 & 126.2 & 0.194 & \\
\hline Butylcyclohexane & $1678-93-9$ & Cycl & 178 & 140.3 & 0.174 & \\
\hline 1,3-Butadiene & $106-99-0$ & Alke & -5 & 54.1 & 0.452 & $\mathrm{H}, \mathrm{T}$ \\
\hline Isoprene & $78-79-5$ & Terp & 34 & 68.1 & 0.359 & \\
\hline$\alpha$-Pinene & $7785-70-8$ & Terp & 155 & 136.2 & 0.180 & \\
\hline Camphene & 5794-04-7 & Terp & 160 & 136.2 & 0.180 & \\
\hline 3-Carene & $13466-78-9$ & Terp & 165 & 136.2 & 0.180 & \\
\hline$\beta$-Pinene & $18172-67-3$ & Terp & 166 & 136.2 & 0.180 & \\
\hline d-Limonene & $5989-27-5$ & Terp & 177 & 136.2 & 0.180 & \\
\hline p-Cymene & $99-87-6$ & Terp & 177 & 134.2 & 0.182 & \\
\hline Benzene & $71-43-2$ & Arom & 80 & 78.1 & 0.313 & $\mathrm{H}, \mathrm{T}$ \\
\hline Toluene & $108-88-3$ & Arom & 111 & 92.1 & 0.265 & $\mathrm{H}, \mathrm{T}$ \\
\hline Ethylbenzene & $100-41-4$ & Arom & 136 & 106.2 & 0.230 & $\mathrm{H}, \mathrm{T}$ \\
\hline m/p-Xylene & & Arom & 139 & 106.2 & 0.230 & \\
\hline o-Xylene & $95-47-6$ & Arom & 143 & 106.2 & 0.230 & $\mathrm{H}, \mathrm{T}$ \\
\hline Styrene & $100-42-5$ & Arom & 145 & 104.2 & 0.235 & $\mathrm{H}, \mathrm{T}$ \\
\hline
\end{tabular}


Table 4. Continued.

\begin{tabular}{|c|c|c|c|c|c|c|}
\hline Compound & $\begin{array}{l}\text { CAS } \\
\text { No. }\end{array}$ & $\begin{array}{l}\text { Chem. } \\
\text { Class }^{\text {a }}\end{array}$ & $\begin{array}{c}\text { BP } \\
\left({ }^{\circ} \mathrm{C}\right) \\
\end{array}$ & MW & $\begin{array}{l}\mu \mathrm{g} / \mathrm{m}^{3} \\
\text { to } \mathrm{ppb}\end{array}$ & $\begin{array}{c}\text { Toxic } \\
\text { Cat. }\end{array}$ \\
\hline Isopropylbenzene (cumene) & $98-82-8$ & Arom & 153 & 120.2 & 0.203 & $\mathrm{H}, \mathrm{T}$ \\
\hline 3/4-Ethyltoluene & & Arom & 159 & 120.2 & 0.203 & \\
\hline Propylbenzene & $103-65-1$ & Arom & 159 & 120.2 & 0.203 & \\
\hline 4-Ethyltoluene & $622-96-8$ & Arom & 162 & 120.2 & 0.203 & \\
\hline 2-Ethyltoluene & $611-14-3$ & Arom & 164 & 120.2 & 0.203 & \\
\hline 1,3,5-Trimethylbenzene & $108-67-8$ & Arom & 165 & 120.2 & 0.203 & \\
\hline 1,2,4-Trimethylbenzene & $95-63-6$ & Arom & 169 & 120.2 & 0.203 & $\mathrm{~T}$ \\
\hline 1,2,3-Trimethylbenzene & $526-73-8$ & Arom & 175 & 120.2 & 0.203 & \\
\hline Butylbenzene & $104-51-8$ & Arom & 183 & 134.2 & 0.182 & \\
\hline Naphthalene & $91-20-3$ & Arom & 218 & 128.2 & 0.191 & $\mathrm{H}, \mathrm{T}$ \\
\hline 4-Phenylcyclohexene & 4994-16-5 & Arom & 252 & 158.2 & 0.155 & \\
\hline Chlorobenzene & $108-90-7$ & ClAro & 132 & 112.6 & 0.217 & $\mathrm{H}, \mathrm{T}$ \\
\hline 1,4-Dichlorobenzene & $106-46-7$ & ClAro & 174 & 147.0 & 0.166 & $\mathrm{H}, \mathrm{T}$ \\
\hline 1,2-Dichlorobenzene & $95-50-1$ & ClAro & 180 & 147.0 & 0.166 & \\
\hline 1,2,4-Trichlorobenzene & $120-82-1$ & ClAro & 213 & 181.4 & 0.135 & $\mathrm{H}, \mathrm{T}$ \\
\hline Vinyl chloride & $75-01-4$ & Halo & -13 & 62.5 & 0.391 & $\mathrm{H}, \mathrm{T}$ \\
\hline Bromomethane & 74-83-9 & Halo & 4 & 94.9 & 0.258 & $\mathrm{H}, \mathrm{T}$ \\
\hline Trichlorofluoromethane & $75-69-4$ & Halo & 24 & 137.4 & 0.178 & $\mathrm{~T}$ \\
\hline Dichloromethane & $75-09-2$ & Halo & 40 & 84.9 & 0.288 & $\mathrm{H}, \mathrm{T}$ \\
\hline Trichlorotrifluoroethane & $76-13-1$ & Halo & 48 & 187.4 & 0.130 & $\mathrm{~T}$ \\
\hline Chloroform & $67-66-3$ & Halo & 62 & 119.4 & 0.205 & $\mathrm{H}, \mathrm{T}$ \\
\hline 1,1,1-Trichloroethane & $71-55-6$ & Halo & 74 & 133.4 & 0.183 & $\mathrm{H}, \mathrm{T}$ \\
\hline Carbon tetrachloride & $56-23-5$ & Halo & 77 & 153.8 & 0.159 & $\mathrm{H}, \mathrm{T}$ \\
\hline 1,2-Dichloroethane & $107-06-2$ & Halo & 83 & 99.0 & 0.247 & $\mathrm{H}, \mathrm{T}$ \\
\hline Trichloroethene & $79-01-6$ & Halo & 87 & 131.4 & 0.186 & $\mathrm{H}, \mathrm{T}$ \\
\hline Tetrachloroethene & $127-18-4$ & Halo & 121 & 165.8 & 0.147 & $\mathrm{H}, \mathrm{T}$ \\
\hline Carbon disulfide & $75-15-0$ & Misc & 46 & 76.1 & 0.321 & $\mathrm{H}, \mathrm{T}$ \\
\hline Acrylonitrile & $107-13-1$ & Misc & 77 & 53.1 & 0.460 & $\mathrm{H}, \mathrm{T}$ \\
\hline Pyridine & $110-86-1$ & Misc & 115 & 79.1 & 0.309 & \\
\hline d4 Siloxane ${ }^{\mathrm{d}}$ & $556-67-2$ & Misc & 175 & 296.6 & 0.082 & \\
\hline d5 Siloxane ${ }^{e}$ & $541-02-6$ & Misc & 210 & 370.8 & 0.066 & \\
\hline Benzothiazole & $95-16-9$ & Misc & 231 & 135.2 & 0.181 & \\
\hline
\end{tabular}

a. Alc $=$ alcohol; Ethr $=$ ether; Gly $=$ glycol ether; Ket $=$ ketone; Ald $=$ aldehyde; Estr $=$ acetates and other esters; Acid = carboxylic acid; Alka $=$ alkane $\mathrm{HC} ;$ Alke $=$ alkene $\mathrm{HC} ; \mathrm{Cycl}=$ cyclic $\mathrm{HC}$; Terp $=$ terpene $\mathrm{HC}$; Arom $=$ aromatic $\mathrm{HC} ; \mathrm{ClAro}=$ chlorinated aromatic $\mathrm{HC} ; \mathrm{Halo}=$ halogenated aliphatic $\mathrm{HC}$; Misc $=$ miscellaneous category

b. 2,2,4-Trimethyl-1,3-pentanediol monisobutyrate (combined isomers $1 \& 3$ )

c. 2,2,4-Trimethyl-1,3-pentanediol diisobutyrate

d. Octamethylcyclotetrasiloxane

e. Decamethylcyclopentasiloxane 
Table 5. Geometric mean (GM), median and mean VOC concentrations in existing residences. For multiple studies, concentrations are summarized as unweighted GMs. Best estimates are calculated as unweighted GMs of reported GM and median concentrations. Numbers of residential units comprising best estimates are shown..

\begin{tabular}{|c|c|c|c|c|c|c|c|}
\hline \multirow[b]{2}{*}{ Compound } & \multirow[b]{2}{*}{$\begin{array}{l}\text { Chem. } \\
\text { Class }\end{array}$} & \multicolumn{3}{|c|}{ Concentration (ppb) } & \multirow[b]{2}{*}{$\begin{array}{l}\text { Best } \\
\text { Est. }\end{array}$} & \multirow[b]{2}{*}{$\begin{array}{l}\text { No. } \\
\text { Units }\end{array}$} & \multirow[b]{2}{*}{$\begin{array}{l}\text { Study } \\
\text { ID }^{\mathrm{a}}\end{array}$} \\
\hline & & $\begin{array}{l}\text { Value } \\
\text { GM }\end{array}$ & $\begin{array}{l}\text { r GM (No. } \\
\text { Median }\end{array}$ & $\begin{array}{l}\text { Studies) } \\
\text { Mean }\end{array}$ & & & \\
\hline 1,4-Dioxane & Ethr & 0.03 & & 0.39 & 0.03 & 128 & $\mathrm{~s}$ \\
\hline 2-Propanone & Ket & & 15 & 30 & 15 & 93 & $\mathrm{hb}$ \\
\hline Formaldehyde & Ald & & 17 & 55 & 17 & 190 & $\mathrm{~g}, \mathrm{za}$ \\
\hline Acetaldehyde & Ald & & & 3.0 & & & $\mathrm{za}$ \\
\hline Propionaldehyde & Ald & & & 1.2 & & & $\mathrm{za}$ \\
\hline Acrolein & Ald & 1.8 & & & 1.8 & 128 & $\mathrm{~s}$ \\
\hline Butanal & Ald & & & 0.66 & & & za \\
\hline 3-Methylbutanal & Ald & & & 0.41 & & & $\mathrm{za}$ \\
\hline Pentanal & Ald & & & 0.91 & & & $\mathrm{za}$ \\
\hline 2-Furaldehyde & Ald & & & 0.27 & & & za \\
\hline Benzaldehyde & Ald & & & 0.38 & & & $\mathrm{za}$ \\
\hline Formic acid & Acid & & & 8.8 & & & za \\
\hline Acetic acid & Acid & & & 24 & & & $\mathrm{za}$ \\
\hline 2-Methylpentane & Alka & & 0.56 & & 0.56 & 9 & $\mathrm{~m}$ \\
\hline 3-Methylpentane & Alka & & 0.33 & & 0.33 & 9 & $\mathrm{~m}$ \\
\hline n-Hexane & Alka & & 0.51 & 0.28 & 0.51 & 9 & $\mathrm{~m}, \mathrm{o}$ \\
\hline n-Heptane & Alka & & 0.26 & & 0.26 & 9 & $\mathrm{~m}$ \\
\hline n-Octane & Alka & & $0.24(2)$ & 0.70 & 0.24 & 19 & $\mathrm{~m} . \mathrm{v}$ \\
\hline n-Nonane & Alka & & $0.25(3)$ & $0.78(2)$ & 0.25 & 151 & ha,hb,m \\
\hline n-Decane & Alka & & $0.44(2)$ & $0.97(2)$ & 0.44 & 142 & ha,hb \\
\hline n-Undecane & Alka & & $0.28(2)$ & $1.3(2)$ & 0.28 & 142 & ha,hb \\
\hline n-Dodecane & Alka & & $0.17(2)$ & $0.55(2)$ & 0.17 & 142 & ha,hb \\
\hline n-Tridecane & Alka & & $0.14(2)$ & $0.31(2)$ & 0.14 & 142 & ha,hb \\
\hline Cyclohexane & Cycl & & 0.18 & & 0.18 & & $\mathrm{~m}$ \\
\hline Methylcyclohexane & Cycl & & 0.40 & & 0.40 & & $\mathrm{~m}$ \\
\hline 1,3-Butadiene & Alke & & $0.23(4)$ & $0.31(2)$ & 0.23 & 302 & $\mathrm{~g}, \mathrm{hb}, \mathrm{m}, \mathrm{v}$ \\
\hline Isoprene & Terp & & $0.54(2)$ & 6.5 & 0.54 & 102 & $\mathrm{hb}, \mathrm{m}$ \\
\hline$\alpha$-Pinene & Terp & & & 4.1 & & & o \\
\hline d-Limonene & Terp & & & 3.6 & & & o \\
\hline p-Cymene & Terp & & & 0.18 & & & 0 \\
\hline Benzene & Arom & $1.0(2)$ & $0.87(7)$ & $1.5(7)$ & 0.90 & 980 & $\begin{array}{c}\text { a,c,f,g,ha,hb, } \\
\text { m,o,s,v }\end{array}$ \\
\hline Toluene & Arom & & $3.3(6)$ & $6.7(5)$ & 3.3 & 641 & $\begin{array}{c}\mathrm{a}, \mathrm{g}, \mathrm{ha}, \mathrm{hb}, \mathrm{m}, \\
\mathrm{o}, \mathrm{v}\end{array}$ \\
\hline Ethylbenzene & Arom & & $0.53(4)$ & $1.4(4)$ & 0.53 & 160 & ha,hb,m,o,v, \\
\hline
\end{tabular}


Table 5. Continued.

\begin{tabular}{|c|c|c|c|c|c|c|c|}
\hline Compound & $\begin{array}{c}\text { Chem. } \\
\text { Class }\end{array}$ & $\begin{array}{l}\text { Value } \\
\text { GM }\end{array}$ & $\begin{array}{l}\text { Concentr } \\
\text { r GM (No } \\
\text { Median }\end{array}$ & $\begin{array}{l}\text { ion (ppb) } \\
\text { Studies) } \\
\text { Mean }\end{array}$ & $\begin{array}{l}\text { Best } \\
\text { Est. }\end{array}$ & $\begin{array}{c}\text { No. } \\
\text { Units }\end{array}$ & $\begin{array}{c}\text { Study } \\
\text { ID }^{\mathrm{a}}\end{array}$ \\
\hline m/p-Xylene & Arom & 1.0 & $1.4(3)$ & $2.9(3)$ & 1.3 & 437 & $\mathrm{a}, \mathrm{m}, \mathrm{s}, \mathrm{v}$ \\
\hline o-Xylene & Arom & 0.44 & $0.53(5)$ & $1.1(6)$ & 0.51 & 579 & $\begin{array}{c}\text { a,ha,hb,m,o, } \\
\text { s,v }\end{array}$ \\
\hline Styrene & Arom & 0.18 & $0.25(5)$ & $0.35(6)$ & 0.23 & 579 & $\begin{array}{c}\text { a,ha,hb,m,o, } \\
\text { s,v }\end{array}$ \\
\hline Isopropylbenzene & Arom & & $0.07(2)$ & $0.12(2)$ & 0.07 & 142 & ha,hb \\
\hline Propylbenzene & Arom & & $0.11(2)$ & $0.25(2)$ & 0.11 & 142 & ha,hb \\
\hline 4-Ethyltoluene & Arom & & 0.55 & & 0.55 & 9 & $\mathrm{~m}$ \\
\hline 2-Ethyltoluene & Arom & & 0.45 & & 0.45 & 9 & $\mathrm{~m}$ \\
\hline 1,3,5-Trimethylbenz & Arom & & $0.25(3)$ & $0.51(3)$ & 0.25 & 151 & ha,hb,m,o \\
\hline 1,2,4-Trimethylbenz & Arom & & 0.79 & 2.4 & 0.79 & 9 & $\mathrm{~m}, \mathrm{o}$ \\
\hline 1,2,3-Trimethylbenz & Arom & & 0.20 & 0.42 & 0.20 & 142 & ha,hb \\
\hline Butylbenzene & Arom & & $0.03(2)$ & $0.06(2)$ & 0.03 & 142 & ha,hb \\
\hline Naphthalene & Arom & & 0.09 & $0.35(2)$ & 0.09 & 10 & $\mathrm{o}, \mathrm{V}$ \\
\hline 4-Phenylcyclohexene & Arom & & & 0.02 & & & $\mathrm{hb}$ \\
\hline 1,4-Dichlorobenzene & ClAro & 0.18 & $0.08(4)$ & $1.3(6)$ & 0.09 & 570 & a,ha,hb,o,s,v \\
\hline 1,2-Dichlorobenzene & ClAro & & & 11 & & & $\mathrm{~V}$ \\
\hline Vinyl chloride & Halo & $0.01(2)$ & $<0.01$ & & 0.01 & 161 & $\mathrm{f}, \mathrm{k}$ \\
\hline Dichloromethane & Halo & $0.88(2)$ & $2.1(2)$ & $6.4(4)$ & 1.4 & 299 & $\mathrm{f}, \mathrm{k}, \mathrm{o}, \mathrm{s}, \mathrm{v}$ \\
\hline Chloroform & Halo & 0.43 & $0.19(5)$ & $0.37(5)$ & 0.22 & 613 & $\begin{array}{c}\mathrm{a}, \mathrm{c}, \mathrm{f}, \mathrm{hb}, \mathrm{m}, \\
\mathrm{o}, \mathrm{v}\end{array}$ \\
\hline 1,1,1-Trichloroethane & Halo & $0.26(3)$ & $0.36(4)$ & $2.4(3)$ & 0.35 & 598 & $\mathrm{a}, \mathrm{f}, \mathrm{k}, \mathrm{m}, \mathrm{s}, \mathrm{v}$ \\
\hline Carbon tetrachloride & Halo & 0.09 & $0.09(2)$ & $0.09(2)$ & 0.09 & 147 & $\mathrm{~m}, \mathrm{~s}, \mathrm{v}$ \\
\hline 1,2-Dichloroethane & Halo & $0.01(2)$ & 0.01 & $0.06(3)$ & 0.01 & 161 & f,ha,hb,k,o \\
\hline Trichloroethene & Halo & $0.04(3)$ & $0.08(8)$ & $0.23(7)$ & 0.07 & 1100 & $\begin{array}{c}\text { a,c,f,g,ha,hb, } \\
\text { k,m,o,s,v }\end{array}$ \\
\hline Tetrachloroethene & Halo & $0.13(3)$ & $0.15(7)$ & $0.41(6)$ & 0.14 & 910 & $\begin{array}{c}\mathrm{a}, \mathrm{c}, \mathrm{f}, \mathrm{ha}, \mathrm{hb}, \mathrm{k}, \\
\mathrm{m}, \mathrm{s}, \mathrm{v}\end{array}$ \\
\hline Pyridine & Misc & & $0.17(2)$ & $0.54(2)$ & 0.17 & 142 & ha,hb \\
\hline
\end{tabular}

a. IDs of all studies reporting values are indicated; study IDs defined in Table 1 
Table 6. Upper percentile $\left(90^{\text {th }}\right.$ and $\left.95^{\text {th }}\right)$ and maximum VOC concentrations in existing residences. Values are shown as ranges for compounds reported by three or more studies. Maximum concentrations for multiple studies are summarized as unweighted GMs.

\begin{tabular}{|c|c|c|c|c|c|c|}
\hline \multirow[b]{3}{*}{ Compound } & \multicolumn{6}{|c|}{ Concentration (ppb) } \\
\hline & \multirow{2}{*}{$\begin{array}{c}\text { Chem. } \\
\text { Class }\end{array}$} & \multicolumn{3}{|c|}{ Value or Range (No. Studies) } & \multirow{2}{*}{$\begin{array}{l}\text { GM } \\
\text { Max } \\
\end{array}$} & \multirow{2}{*}{$\begin{array}{c}\text { Study } \\
\text { ID }^{\mathrm{a}}\end{array}$} \\
\hline & & $90 \%$ ile & $95 \%$ ile & Max & & \\
\hline 1,4-Dioxane & Ethr & 0.18 & & 39 & & $\mathrm{~s}$ \\
\hline 2-Propanone & Ket & & & 280 & & $\mathrm{hb}$ \\
\hline Formaldehyde & Ald & 37 & & 100,330 & 180 & $\mathrm{za}, \mathrm{g}$ \\
\hline Acetaldehyde & Ald & & & 16 & & $\mathrm{za}$ \\
\hline Propionaldehyde & Ald & & & 5.6 & & $\mathrm{za}$ \\
\hline Acrolein & Ald & 9.2 & & 13 & & $\mathrm{~s}$ \\
\hline Butanal & Ald & & & 2.4 & & za \\
\hline 3-Methylbutanal & Ald & & & 1.2 & & $\mathrm{za}$ \\
\hline Pentanal & Ald & & & 2.0 & & $\mathrm{za}$ \\
\hline 2-Furaldehyde & Ald & & & 1.5 & & $\mathrm{za}$ \\
\hline Benzaldehyde & Ald & & & 1.3 & & $\mathrm{za}$ \\
\hline Formic acid & Acid & & & 19 & & $\mathrm{zb}$ \\
\hline Acetic acid & Acid & & & 81 & & $\mathrm{zb}$ \\
\hline n-Octane & Alka & 2.4 & & 3.6 & & $\mathrm{~V}$ \\
\hline n-Nonane & Alka & & & $3.2,14$ & 6.7 & ha,hb \\
\hline n-Decane & Alka & & & $7.9,20$ & 13 & ha,hb \\
\hline n-Undecane & Alka & & & $9.2,39$ & 19 & hb,ha \\
\hline n-Dodecane & Alka & & & $4.1,18$ & 8.7 & hb,ha \\
\hline n-Tridecane & Alka & & & $2.1,5.2$ & 3.3 & ha,hb \\
\hline 1,3-Butadiene & Alke & $0.17,0.53$ & & $0.27-5.5(4)$ & 1.7 & $\mathrm{~g}, \mathrm{hb}, \mathrm{s}, \mathrm{V}$ \\
\hline Isoprene & Terp & & & 24 & & $\mathrm{hb}$ \\
\hline Benzene & Arom & $1.9-4.1(4)$ & 4.0 & $8.4-41(7)$ & 41 & $\begin{array}{c}\mathrm{a}, \mathrm{c}, \mathrm{f}, \mathrm{g}, \mathrm{ha}, \mathrm{hb}, \\
\mathrm{s}, \mathrm{v}\end{array}$ \\
\hline Toluene & Arom & $7.8,13$ & & $12-240(5)$ & 47 & a,g,ha,hb,v \\
\hline Ethylbenzene & Arom & 3.0 & & $5.9-40(3)$ & 11 & ha,hb,v \\
\hline $\mathrm{m} / \mathrm{p}$-Xylene & Arom & $2.8,13$ & 5.0 & $28-120(3)$ & 67 & $\mathrm{a}, \mathrm{s}, \mathrm{v}$ \\
\hline o-Xylene & Arom & $1.3,3.7$ & 1.6 & $7.9-43(5)$ & 14 & a,ha,hb,s,v \\
\hline Styrene & Arom & $0.50,0.89$ & 0.56 & $1.7-33(5)$ & 5.5 & $\mathrm{a}, \mathrm{ha}, \mathrm{hb}, \mathrm{s}, \mathrm{v}$ \\
\hline Isopropylbenzene & Arom & & & $0.66,2.1$ & 1.2 & ha,hb \\
\hline Propylbenzene & Arom & & & $2.0,6.1$ & 3.5 & ha,hb \\
\hline 1,3,5-Trimethylbenz & Arom & & & $3.1,14$ & 6.5 & ha,hb \\
\hline 1,2,3-Trimethylbenz & Arom & & & $2.2,7.9$ & 4.2 & ha,hb \\
\hline Butylbenzene & Arom & & & $0.3,2.3$ & 0.80 & ha,hb \\
\hline Naphthalene & Arom & 0.41 & & 0.95 & & $\mathrm{v}$ \\
\hline 4-Phenylcyclohexene & Arom & & & 0.29 & & $\mathrm{hb}$ \\
\hline Chlorobenzene & ClAro & & & 0.11 & & $\mathrm{~s}$ \\
\hline
\end{tabular}


Table 6. Continued.

\begin{tabular}{|c|c|c|c|c|c|c|}
\hline \multirow[b]{3}{*}{ Compound } & \multicolumn{6}{|c|}{ Concentration (ppb) } \\
\hline & Chem. & Value or & Range (No. & Studies) & GM & Study \\
\hline & Class & $90 \%$ ile & $95 \%$ ile & Max & Max & $\mathrm{ID}^{\mathrm{a}}$ \\
\hline 1,4-Dichlorobenzene & ClAro & $0.34,4.7$ & 0.57 & $16-50(5)$ & 26 & $\mathrm{a}, \mathrm{ha}, \mathrm{hb}, \mathrm{s}, \mathrm{v}$ \\
\hline 1,2-Dichlorobenzene & ClAro & 0.04 & & 0.09 & & $\mathrm{v}$ \\
\hline Vinyl chloride & Halo & & 0.04 & $0.13,0.20$ & 0.16 & $\mathrm{f}, \mathrm{k}$ \\
\hline Bromomethane & Halo & & & 0.72 & & $\mathrm{~s}$ \\
\hline Dichloromethane & Halo & 46,150 & 4.6 & $3.5-490(4)$ & 74 & $\mathrm{f}, \mathrm{k}, \mathrm{s}, \mathrm{V}$ \\
\hline Chloroform & Halo & $0.83,1.3$ & 1.2 & $1.2-4.3(4)$ & 2.6 & $\mathrm{a}, \mathrm{c}, \mathrm{f}, \mathrm{hb}, \mathrm{v}$ \\
\hline 1,1,1-Trichloroethane & Halo & $2.2,12$ & $1.4,3.2$ & $2.6-180(5)$ & 28 & $\mathrm{a}, \mathrm{f}, \mathrm{k}, \mathrm{s}, \mathrm{v}$ \\
\hline Carbon tetrachloride & Halo & $0.11,0.15$ & & $0.20,0.41$ & 0.29 & $\mathrm{~s}, \mathrm{~V}$ \\
\hline 1,2-Dichloroethane & Halo & & 0.04 & $0.10-2.4(4)$ & 0.26 & f,ha,hb,k \\
\hline Trichloroethene & Halo & $0.21-0.42(4)$ & $0.13,0.26$ & $0.58-5.0(7)$ & 1.9 & $\begin{array}{c}\text { a,c,f,g,ha,hb, } \\
\text { k,s,v }\end{array}$ \\
\hline Tetrachloroethene & Halo & $0.34-1.0(3)$ & $0.72,1.0$ & $0.76-65(7)$ & 7.0 & $\begin{array}{c}\mathrm{a}, \mathrm{c}, \mathrm{f}, \mathrm{ha}, \mathrm{hb}, \mathrm{k}, \\
\mathrm{s}, \mathrm{v}\end{array}$ \\
\hline Pyridine & Misc & & & $1.5,2.7$ & 2.0 & hb,ha \\
\hline Acrylonitrile & Misc & & & 12 & & $\mathrm{~S}$ \\
\hline
\end{tabular}

a. IDs of all studies reporting values are indicated; study IDs defined in Table 1 
Table 7. Geometric mean (GM) and maximum VOC concentrations in new single-family houses. Concentrations reported by both studies are summarized as unweighted GMs.

\begin{tabular}{|c|c|c|c|c|}
\hline \multirow[b]{2}{*}{ Compound } & \multirow{2}{*}{$\begin{array}{l}\text { Chem. } \\
\text { Class }\end{array}$} & \multicolumn{2}{|c|}{ Concentration (ppb) } & \multirow{2}{*}{$\begin{array}{l}\text { Study } \\
\text { ID }^{\text {a }}\end{array}$} \\
\hline & & GM & Maximum & \\
\hline 1-Butanol & Alc & 7.7 & 21 & ho \\
\hline Phenol & Alc & 1.8 & 5.8 & ho \\
\hline 2-Ethyl-1-hexanol & Alc & $<1.5$ & & ho \\
\hline 1-Octanol & Alc & $<1.5$ & & ho \\
\hline BHT & Alc & $<0.5$ & & ho \\
\hline Ethylene glycol & Gly & 48 & 490 & ho \\
\hline 2-Butoxyethanol & Gly & 2.9 & 12 & ho \\
\hline 1,2-Propanediol & Gly & 4.8 & 360 & ho \\
\hline DEGBE & Gly & $<1.5$ & & ho \\
\hline 2-Propanone & Ket & 28 & 210 & 1 \\
\hline 2-Butanone & Ket & 6.4 & 37 & ho,1 \\
\hline 4-Methyl-2-pentanone & Ket & $<0.5$ & & ho \\
\hline Cyclohexanone & Ket & $<0.5$ & & ho \\
\hline 1-Phenylethanone & Ket & $<1.5$ & & ho \\
\hline Formaldehyde & Ald & 32 & 62 & ho,1 \\
\hline Acetaldehyde & Ald & 14 & 43 & ho,1 \\
\hline Propionaldehyde & Ald & 4.4 & 19 & 1 \\
\hline Butanal & Ald & 0.30 & 2.0 & 1 \\
\hline Pentanal & Ald & 2.5 & 9.8 & 1 \\
\hline Hexanal & Ald & 15 & 36 & ho,1 \\
\hline Heptanal & Ald & 1.9 & 4.9 & ho \\
\hline 2-Furaldehyde & Ald & $<1.5$ & & ho \\
\hline Octanal & Ald & 2.6 & 7.2 & ho \\
\hline Benzaldehyde & Ald & 1.3 & 3.7 & 1 \\
\hline Nonanal & Ald & 3.1 & 7.6 & ho \\
\hline Ethyl acetate & Estr & $<0.5$ & & ho \\
\hline Butyl acetate & Estr & 1.4 & 14 & ho \\
\hline TMPD-MIB $^{\mathrm{b}}$ & Estr & 5.6 & 25 & ho \\
\hline TMPD-DIB $^{\mathrm{c}}$ & Estr & 1.3 & 7.2 & ho \\
\hline Acetic acid & Acid & 71 & 280 & ho \\
\hline Hexanoic acid & Acid & 1.1 & 5.5 & ho \\
\hline n-Heptane & Alka & $<1.5$ & & ho \\
\hline n-Nonane & Alka & $<1.5$ & & ho \\
\hline n-Decane & Alka & 3.9 & 22 & ho \\
\hline n-Undecane & Alka & 2.3 & 9.1 & ho \\
\hline n-Dodecane & Alka & 3.6 & 11 & ho \\
\hline n-Tridecane & Alka & 5.2 & 21 & ho \\
\hline n-Tetradecane & Alka & $<5.0$ & & ho \\
\hline
\end{tabular}


Table 7. Continued.

\begin{tabular}{|c|c|c|c|c|}
\hline \multirow[b]{2}{*}{ Compound } & \multirow{2}{*}{$\begin{array}{l}\text { Chem. } \\
\text { Class }\end{array}$} & \multicolumn{2}{|c|}{ Concentration (ppb) } & \multirow{2}{*}{$\begin{array}{c}\text { Study } \\
\text { ID }^{\mathrm{a}}\end{array}$} \\
\hline & & GM & Maximum & \\
\hline n-Pentadecane & Alka & $<0.5$ & & ho \\
\hline n-Hexadecane & Alka & $<0.5$ & & ho \\
\hline Methylcyclohexane & Cycl & $<1.5$ & & ho \\
\hline Propylcyclohexane & Cycl & $<0.5$ & & ho \\
\hline Butylcyclohexane & Cycl & $<0.5$ & & ho \\
\hline$\alpha$-Pinene & Terp & 23 & 60 & ho \\
\hline Camphene & Terp & $<1.5$ & & ho \\
\hline 3-Carene & Terp & 4.1 & 15 & ho \\
\hline$\beta$-Pinene & Terp & 8.0 & 26 & ho \\
\hline d-Limonene & Terp & 4.3 & 12 & ho \\
\hline Benzene & Arom & 0.47 & 6.1 & 1 \\
\hline Toluene & Arom & 8.5 & 68 & ho,l \\
\hline Ethylbenzene & Arom & 0.32 & 2.1 & 1 \\
\hline m/p-Xylene & Arom & 2.1 & 11 & ho,l \\
\hline o-Xylene & Arom & 0.64 & 4.4 & 1 \\
\hline Styrene & Arom & 0.59 & 7.8 & ho,l \\
\hline 1,3,5-Trimethylbenzene & Arom & $<0.5$ & & ho \\
\hline 1,2,4-Trimethylbenzene & Arom & $<1.5$ & & ho \\
\hline Naphthalene & Arom & $<1.5$ & & ho \\
\hline 4-Phenylcyclohexene & Arom & $<0.5$ & & ho \\
\hline Chlorobenzene & ClAro & 0.17 & 0.32 & 1 \\
\hline 1,2-Dichlorobenzene & ClAro & 0.22 & 0.54 & 1 \\
\hline Trichlorofluoromethane & Halo & 0.55 & 1.3 & 1 \\
\hline Dichloromethane & Halo & 0.29 & 2.3 & 1 \\
\hline Trichlorotrifluoroethane & Halo & 0.17 & 1.2 & 1 \\
\hline Chloroform & Halo & 0.06 & 0.47 & 1 \\
\hline 1,1,1-Trichloroethane & Halo & 0.46 & 2.3 & 1 \\
\hline Trichloroethene & Halo & 0.06 & 0.43 & 1 \\
\hline Tetrachloroethene & Halo & 0.06 & 0.29 & 1 \\
\hline Benzothiazole & Misc & $<0.5$ & & ho \\
\hline
\end{tabular}

a. Study IDs defined in Table 2

b. 2,2,4-Trimethyl-1,3-pentanediol monisobutyrate (combined isomers $1 \& 3$ )

c. 2,2,4-Trimethyl-1,3-pentanediol diisobutyrate 
Table 8. Central tendency (GM or median) and maximum VOC concentrations in existing office buildings. Concentrations reported by multiple studies are summarized as unweighted GMs.

\begin{tabular}{|c|c|c|c|c|c|}
\hline \multirow[b]{2}{*}{ Compound } & \multirow[b]{2}{*}{$\begin{array}{c}\text { Chem. } \\
\text { Class }\end{array}$} & \multicolumn{2}{|c|}{ Central Tendency } & \multicolumn{2}{|c|}{ Maximum } \\
\hline & & $\begin{array}{l}\text { Conc. } \\
\text { (ppb) }\end{array}$ & Study ID ${ }^{\mathrm{a}}$ & $\begin{array}{l}\text { Conc. } \\
\text { (ppb) }\end{array}$ & Study ID ${ }^{\mathrm{a}}$ \\
\hline Ethanol & Alc & 19 & $\mathrm{~d}$ & 130 & $\mathrm{~d}$ \\
\hline 2-Propanol & Alc & 2.3 & $\mathrm{~d}$ & 62 & $\mathrm{~d}$ \\
\hline 1-Butanol & Alc & & & 5.0 & gi \\
\hline Phenol & Alc & & & 2.5 & gi \\
\hline 2-Ethyl-1-hexanol & Alc & & & 9.0 & gi \\
\hline$t$-Butyl methyl ether & Ethr & & & 8.3 & gi \\
\hline 2-Butoxyethanol & Gly & 0.65 & d,gi,sh & 14 & d,gi,sh \\
\hline 2-Propanone & Ket & 7.4 & d,gi & 33 & d,gi \\
\hline 2-Butanone & Ket & & & 6.1 & gi \\
\hline 4-Methyl-2-pentanone & Ket & & & 6.8 & gi \\
\hline 1-Phenylethanone & Ket & 1.0 & $\mathrm{~d}$ & 2.8 & d,gi \\
\hline Pentanal & Ald & 0.17 & $\mathrm{~d}$ & 1.3 & d,gi \\
\hline Hexanal & Ald & 0.47 & d,gi & 2.4 & d,gi \\
\hline Benzaldehyde & Ald & 0.47 & $\mathrm{~d}$ & 1.5 & $\mathrm{~d}$ \\
\hline Nonanal & Ald & 0.52 & gi & 1.4 & gi \\
\hline Ethyl acetate & Estr & 0.34 & $\mathrm{~d}$ & 7.4 & d,gi \\
\hline Butyl acetate & Estr & 0.21 & $\mathrm{~d}$ & 3.9 & d,gi \\
\hline TMPD-MIB $^{\mathrm{b}}$ & Estr & 0.06 & sh & 3.2 & gi \\
\hline TMPD-DIB $^{\mathrm{c}}$ & Estr & 0.20 & sh & 0.88 & gi,sh \\
\hline Diethyl phthalate & Estr & $<0.01$ & sh & 0.66 & sh \\
\hline n-Pentane & Alka & 2.5 & $\mathrm{~d}$ & 8.9 & $\mathrm{~d}$ \\
\hline 3-Methylpentane & Alka & & & 4.5 & gi \\
\hline n-Hexane & Alka & 0.62 & d,gi & 3.1 & d,gi \\
\hline 3-Methylhexane & Alka & 0.34 & $\mathrm{~d}$ & 0.71 & $\mathrm{~d}$ \\
\hline n-Heptane & Alka & 0.40 & $\mathrm{~d}$ & 0.72 & $\mathrm{~d}$ \\
\hline 2,2,5-Trimethylhexane & Alka & 0.14 & $\mathrm{~d}$ & 0.31 & $\mathrm{~d}$ \\
\hline n-Octane & Alka & 0.11 & $\mathrm{~d}, \mathrm{sh}$ & 13 & d,gi \\
\hline n-Nonane & Alka & 0.36 & $\mathrm{~d}$ & 5.6 & d,gi \\
\hline n-Decane & Alka & 0.69 & $\mathrm{~d}, \mathrm{sh}$ & 5.8 & $\mathrm{~d}, \mathrm{gi}$ \\
\hline n-Undecane & Alka & 0.65 & d & 10 & d,gi \\
\hline n-Dodecane & Alka & 0.86 & $\mathrm{~d}, \mathrm{gi}, \mathrm{sh}$ & 16 & d,gi \\
\hline n-Tetradecane & Alka & 1.4 & sh & & \\
\hline n-Pentadecane & Alka & 1.5 & sh & & \\
\hline n-Hexadecane & Alka & 1.2 & sh & & \\
\hline Methylcyclopentane & Cycl & 0.45 & $\mathrm{~d}$ & 1.2 & $\mathrm{~d}$ \\
\hline Methylcyclohexane & Cycl & 0.38 & $\mathrm{~d}$ & 0.76 & $\mathrm{~d}$ \\
\hline$\alpha$-Pinene & Terp & 0.04 & sh & 1.5 & gi \\
\hline
\end{tabular}


Table 8. Continued.

\begin{tabular}{|c|c|c|c|c|c|}
\hline \multirow[b]{2}{*}{ Compound } & \multirow[b]{2}{*}{$\begin{array}{l}\text { Chem. } \\
\text { Class }\end{array}$} & \multicolumn{2}{|c|}{ Central Tendency } & \multicolumn{2}{|c|}{ Maximum } \\
\hline & & $\begin{array}{l}\text { Conc. } \\
\text { (ppb) }\end{array}$ & Study ID & $\begin{array}{l}\text { Conc. } \\
(\mathrm{ppb})\end{array}$ & Study ID \\
\hline d-Limonene & Terp & 1.2 & d,gi,sh & 12 & d,gi \\
\hline Benzene & Arom & 1.0 & d,gi & 3.8 & d,gi \\
\hline Toluene & Arom & 2.1 & d,gi,sh & 40 & d,gi \\
\hline Ethylbenzene & Arom & 0.48 & $\mathrm{~d}, \mathrm{sh}$ & 2.6 & d,gi \\
\hline m/p-Xylene & Arom & 1.4 & d,gi,sh & 10 & d,gi \\
\hline o-Xylene & Arom & 0.66 & d & 3.5 & d,gi \\
\hline Styrene & Arom & 0.40 & $\mathrm{~d}$ & 1.2 & d,gi \\
\hline 3/4-Ethyltoluene & Arom & 0.75 & $\mathrm{~d}$ & 1.7 & $\mathrm{~d}$ \\
\hline 4-Ethyltoluene & Arom & & & 2.2 & gi \\
\hline 2-Ethyltoluene & Arom & 0.48 & d & 0.98 & d \\
\hline $1,3,5$-Trimethylbenzene & Arom & 0.38 & $\mathrm{~d}$ & 1.1 & d,gi \\
\hline $1,2,4$-Trimethylbenzene & Arom & 0.88 & $\mathrm{~d}, \mathrm{sh}$ & 2.9 & d,gi \\
\hline $1,2,3$-Trimethylbenzene & Arom & 0.29 & $\mathrm{~d}$ & 1.1 & $\mathrm{~d}$ \\
\hline Naphthalene & Arom & & & 1.9 & gi \\
\hline 4-Phenylcyclohexene & Arom & & & 0.09 & gi \\
\hline Chlorobenzene & ClAro & & & 0.15 & gi \\
\hline 1,4-Dichlorobenzene & ClAro & 0.03 & sh & 7.0 & gi,sh \\
\hline 1,2-Dichlorobenzene & ClAro & & & 2.2 & gi \\
\hline 1,2,4-Trichlorobenzene & ClAro & & & 0.16 & gi \\
\hline Trichlorofluoromethane & Halo & 0.75 & $\mathrm{~d}$ & 13 & d,gi \\
\hline Dichloromethane & Halo & 0.40 & $\mathrm{~d}$ & 65 & d,gi \\
\hline Trichlorotrifluoroethane & halo & & & 3.0 & gi \\
\hline Chloroform & Halo & & & 2.0 & gi \\
\hline $1,1,1$-Trichloroethane & Halo & 1.6 & d,gi & 77 & d,gi \\
\hline Carbon tetrachloride & Halo & & & 0.62 & gi \\
\hline Trichloroethene & Halo & 1.8 & $\mathrm{~d}$ & 4.8 & d,gi \\
\hline Tetrachloroethene & Halo & 0.47 & $\mathrm{~d}, \mathrm{sh}$ & 3.8 & d,gi \\
\hline Carbon disulfide & Misc & & & 5.8 & gi \\
\hline d4 Siloxane ${ }^{d}$ & Misc & 0.84 & $\mathrm{sh}$ & & \\
\hline d5 Siloxane ${ }^{e}$ & Misc & 2.6 & sh & & \\
\hline
\end{tabular}

a. Study IDs defined in Table 3

b. 2,2,4-Trimethyl-1,3-pentanediol monisobutyrate (combined isomers $1 \& 3$ )

c. 2,2,4-Trimethyl-1,3-pentanediol diisobutyrate

d. Octamethylcyclotetrasiloxane

e. Decamethylcyclopentasiloxane 
Table 9. Comparison of central tendency and maximum VOC concentrations between unoccupied new residences and occupied existing residences. Only VOCs with substantial differences are shown. Concentrations that are more than three times higher in new residences are indicated in bold. Concentrations that are more than three times lower in new residences are indicated in underlined italics.

\begin{tabular}{|c|c|c|c|c|c|}
\hline \multirow[b]{3}{*}{ Compound } & \multirow[b]{3}{*}{ Class } & \multicolumn{4}{|c|}{ Concentration $(\mathrm{ppb})$} \\
\hline & & \multicolumn{2}{|c|}{ Central Tendency } & \multicolumn{2}{|c|}{ Maximum } \\
\hline & & Existing & New & Existing & New \\
\hline Formaldehyde & Ald & 17 & 32 & 180 & 62 \\
\hline Acetaldehyde & Ald & 3.0 & 14 & 16 & 43 \\
\hline Propionaldehyde & Ald & 1.2 & 4.4 & 5.6 & 19 \\
\hline Pentanal & Ald & 0.91 & 2.5 & 2.0 & 9.8 \\
\hline Benzaldehyde & Ald & 0.38 & 1.3 & 1.3 & 3.7 \\
\hline Acetic acid & Acid & 24 & 71 & 81 & 280 \\
\hline n-Decane & Alka & 0.44 & 3.9 & 13 & 22 \\
\hline n-Undecane & Alka & 0.28 & 2.3 & 19 & 9.1 \\
\hline n-Dodecane & Alka & 0.17 & 3.6 & 8.7 & 11 \\
\hline n-Tridecane & Alka & 0.14 & 5.2 & 3.3 & 21 \\
\hline$\alpha$-Pinene & Terp & 4.1 & 60 & & \\
\hline d-Limonene & Terp & 3.6 & 12 & & \\
\hline Ethylbenzene & Arom & 0.53 & 0.32 & 11 & $\underline{2.1}$ \\
\hline $\mathrm{m} / \mathrm{p}$-Xylene & Arom & 1.3 & 2.1 & 67 & $\overline{10}$ \\
\hline o-Xylene & Arom & 0.51 & 0.64 & 14 & $\overline{4.4}$ \\
\hline 1,2-Dichlorobenzene & ClAro & & & 0.09 & $\overline{0.54}$ \\
\hline Dichloromethane & Halo & 1.4 & $\underline{0.29}$ & 74 & $\underline{2.3}$ \\
\hline Chloroform & Halo & 0.22 & $\underline{0.06}$ & 2.6 & $\underline{0.47}$ \\
\hline 1,1,1-Trichloroethane & Halo & 0.35 & 0.46 & 28 & 2.3 \\
\hline Trichloroethene & Halo & 0.07 & 0.06 & 1.9 & $\overline{0.43}$ \\
\hline Tetrachloroethene & Halo & 0.14 & 0.06 & 7.0 & $\underline{0.29}$ \\
\hline
\end{tabular}


Table 10. Comparison of central tendency and maximum VOC concentrations between office buildings and existing residences. Only compounds with substantial differences are shown. Concentrations that are more than a factor of three higher in office buildings are indicated in bold. Concentrations that are more than a factor of three lower in office buildings are indicated in underlined italics.

\begin{tabular}{|c|c|c|c|c|c|}
\hline \multirow[b]{3}{*}{ Compound } & \multirow[b]{3}{*}{ Class } & \multicolumn{4}{|c|}{ Concentration $(\mathrm{ppb})$} \\
\hline & & \multicolumn{2}{|c|}{ Central Tendency } & \multicolumn{2}{|c|}{ Maximum } \\
\hline & & Resid. & Office & Resid. & Office \\
\hline 2-Propanone & Ket & 15 & 7.4 & 280 & $\underline{33}$ \\
\hline Pentanal & Ald & 0.91 & $\underline{0.17}$ & 2.0 & $\overline{1.3}$ \\
\hline n-Octane & Alka & 0.24 & $\overline{0.11}$ & 3.6 & 13 \\
\hline n-Dodecane & Alka & 0.17 & 0.86 & 8.7 & 16 \\
\hline$\alpha$-Pinene & Terp & 4.1 & $\underline{0.04}$ & & \\
\hline d-Limonene & Terp & 3.6 & $\overline{1.2}$ & & \\
\hline Benzene & Arom & 0.90 & $\overline{1.0}$ & 18 & $\underline{3.8}$ \\
\hline Ethylbenzene & Arom & 0.53 & 0.48 & 11 & $\underline{2.6}$ \\
\hline m/p-Xylene & Arom & 1.3 & 1.4 & 67 & $\underline{10}$ \\
\hline o-Xylene & Arom & 0.51 & 0.66 & 14 & $\underline{3.5}$ \\
\hline 1,3,5-Trimethylbenzene & Arom & 0.25 & 0.38 & 6.5 & $\overline{1.1}$ \\
\hline 1,2,3-Trimethylbenzene & Arom & 0.20 & 0.29 & 4.2 & $\overline{1.1}$ \\
\hline 4-Phenylcyclohexene & Arom & & & 0.29 & $\overline{0.09}$ \\
\hline 1,4-Dichlorobenzene & ClAro & 0.09 & $\underline{0.03}$ & 26 & $\overline{7.0}$ \\
\hline 1,2-Dichlorobenzene & ClAro & & & 0.09 & $\overline{2.2}$ \\
\hline Dichloromethane & Halo & 1.4 & $\underline{0.40}$ & 74 & 65 \\
\hline 1,1,1-Trichloroethane & Halo & 0.35 & $\overline{1.6}$ & 28 & 77 \\
\hline Trichloroethene & Halo & 0.07 & 1.8 & 1.9 & 4.8 \\
\hline Tetrachloroethene & Halo & 0.14 & 0.47 & 7.0 & 3.8 \\
\hline
\end{tabular}




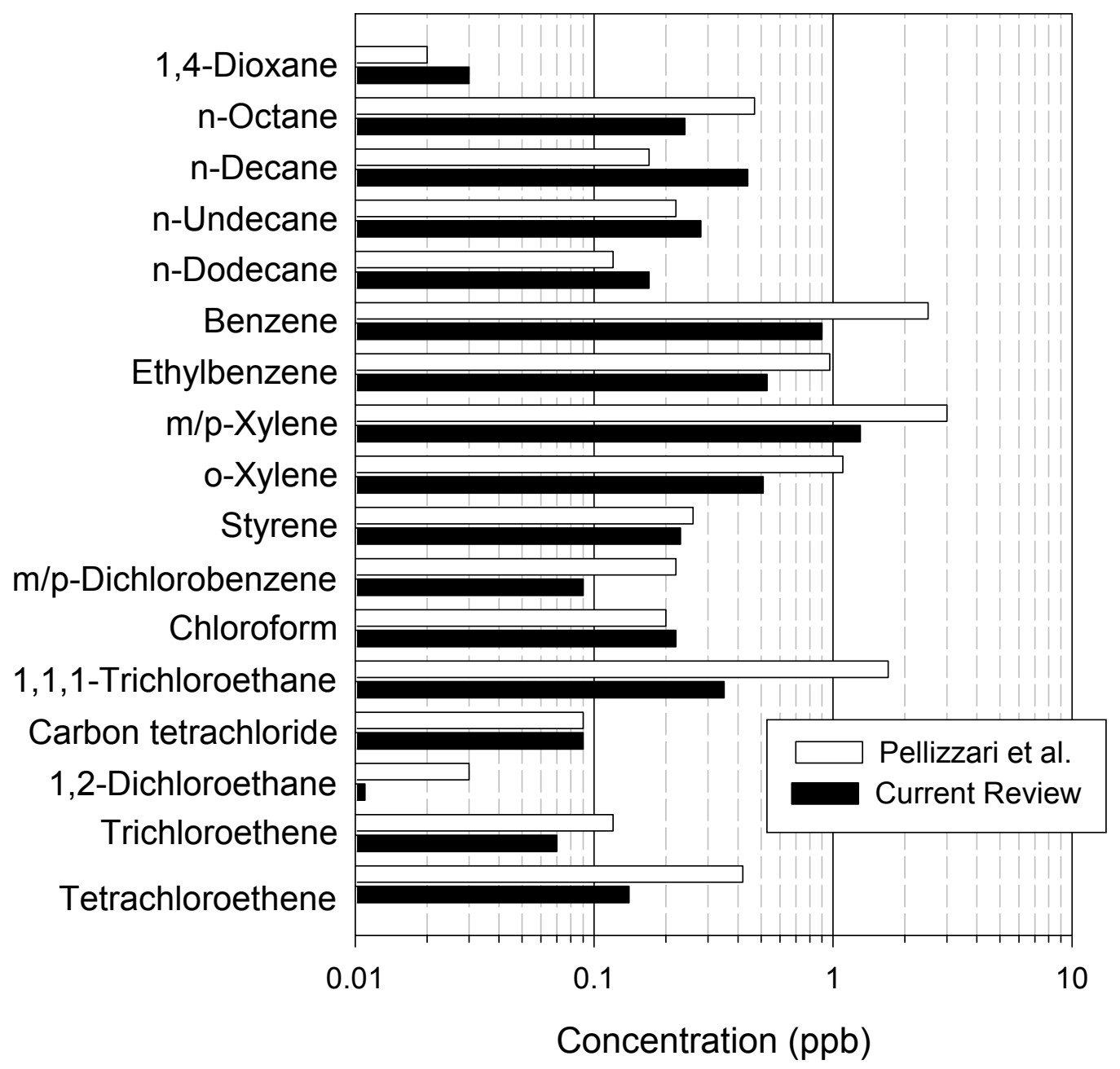

Figure 1. Comparison of central tendency VOC concentrations in existing residences from current review with unweighted GM VOC concentrations from the 1980-84 U.S. EPA TEAM studies (Pellizzari et al., 1986) 